\title{
Expression of Int-2 Oncogene in Kaposi's Sarcoma Lesions
}

\author{
Yao Qi Huang, * Jian Jun Li, * David Moscatelli, ${ }^{\star}$ Claudio Basilico, * \\ Alexander Nicolaides, * Wei Guo Zhang, * Bernard J. Poiesz," and Alvin E. Friedman-Kien *\$ \\ Department of ${ }^{*}$ Microbiology, ${ }^{\ddagger}$ Cell Biology, and ${ }^{\S}$ Dermatology, New York University Medical Center, \\ New York 10016; and Department of "Medicine Upstate Medical Center, Syracuse, New York 13210
}

\begin{abstract}
Fibroblast growth factors (FGFs), such as basic FGF, have been implicated in the growth of Kaposi's sarcoma (KS) cells in vitro. In the evaluation of the expression of the various genes of the different members of the FGF family and their receptors in fresh KS tissue specimens, int-2 was found to be expressed in more than half of the KS tumors examined. Using reverse transcription PCR, the expression of int-2 was detected in 21 of 38 (55.2\%) fresh KS biopsy specimens. In contrast, int-2 mRNA transcripts were not found in normal appearing skin from the same patients except in one sample which was obtained from an AIDS patient with disseminated KS lesions. Sequence data confirmed that the amplified sequences were derived from int-2 mRNA with proper splicing. In addition, 12 nucleic acid alterations were identified in eight out of nine KS tumor samples sequenced. Using immunohistochemical methods, int-2 protein was detected in some of the spindle-shaped tumor cells surrounding the abnormal endothelial-lined vascular slits histologically characteristic of KS. Int-2 specific immunostaining was shown to be present in both the nuclei and cytoplasm of these spindle cells but was more pronounced in the nuclei. Neither amplification nor gross rearrangement of the int-2 gene was detected in KS lesions by Southern blot analysis. These results suggest that the expression of int- 2 may play a role in the pathogenesis KS by stimulating local angiogenesis and cell proliferation. (J. Clin. Invest. 1993. 91:1191-1197.) Key words: Kaposi's sarcoma • polymerase chain reaction • Int-2 • oncogene $\bullet$ fibroblast growth factors
\end{abstract}

\section{Introduction}

Kaposi's sarcoma $(\mathrm{KS})^{1}$ represents an opportunistic tumor of unknown etiology which is the most common neoplastic dis-

\footnotetext{
Address correspondence to Dr. A. E. Friedman-Kien, New York University Medical Center, 550 First Avenue, New York, NY 10016.

Received for publication 30 July 1992 and in revised form 30 November 1992.
}

1. Abbreviations used in this paper: bFGF, basic fibroblast growth factor; FGF, fibroblast growth factor; KS, Kaposi's sarcoma; RT-PCR, reverse transcription PCR.

J. Clin. Invest.

(C) The American Society for Clinical Investigation, Inc.

$0021-9738 / 93 / 03 / 1191 / 07 \quad \$ 2.00$

Volume 91, March 1993, 1191-1197 order seen in individuals infected with HIV, especially homosexual men (1). The characteristic histopathologic features of KS include bizarre shaped endothelial lined vascular slits surrounded by fasicles of spindle-shaped cells and a mononuclear cell infiltrate. In vitro studies on KS-derived cells have shown the potential roles of various cytokines and growth factors, including basic fibroblast growth factor (bFGF), IL-1 $\beta$, IL-6, PDGF, and oncostatin M in the pathogenesis of KS (26 ). The FGFs are of particular interest since they are known to possess the ability to promote the proliferation of a variety of cells of mesodermal origin and have been shown to stimulate neovascularization, one of the primary characteristics of KS. Some of the members of the FGF family also induce cell transformation (7). Although bFGF has been implicated in the development of $\mathrm{KS}$, its pathogenic role for $\mathrm{KS}$ in vivo remains to be determined since bFGF is also strongly expressed in normal skin and appears to be absent from the endothelial cells and the predominant spindle-shaped cells of KS lesions $(8,9)$. We have evaluated the expression of the various genes of the FGF family including aFGF, bFGF, int-2, HST/K-FGF, FGF5, FGF6 and their receptors, FGFR-1 (flg) and FGFR-2(bek), in fresh KS biopsy specimens, uninvolved normal appearing skin from KS patients, or normal skin from healthy individuals. Although some of the other FGFs and the FGF receptors are expressed in some KS tissues ( J. J. Li, et al., manuscript submitted), the most striking observation is that int- 2 is expressed in more than half of the KS tumor tissues examined while almost no expression of int- 2 was found in normal skin. To date there are no previous reports that show such a high prevalence of int- 2 expression in adult human tissues.

\section{Methods}

Specimens. Samples of fresh KS lesions were obtained by either biopsy or autopsy. 10 normal appearing skin specimens were biopsied from HIV-1 positive individuals with KS and two biopsies of normal skin from HIV-1 sero-negative individuals undergoing plastic surgery ( Table I).

Reverse transcription-PCR (RT-PCR). RNAs were extracted from either KS lesion or normal skin by acid guanidinum thiocyanate/ phenol/chloroform extraction, and RT-PCR was performed as was described previously $(10,11)$. Briefly, $1 \mu \mathrm{g}$ of total RNA was incubated with $4 \mathrm{U}$ of ribonuclease-free deoxyribonuclease (Promega Biotec, Madison, WI ) at $37^{\circ} \mathrm{C}$ for $45 \mathrm{~min}$. The enzyme was subsequently heat inactivated (at $95^{\circ} \mathrm{C}$ for $5 \mathrm{~min}$ ) and reverse transcription was carried out for $1 \mathrm{~h}$ at $37^{\circ} \mathrm{C}$ in a volume of $20 \mu \mathrm{l}$ which contained $100 \mathrm{ng}$ of random hexamer, $225 \mu \mathrm{M}$ of each dNTP, $50 \mathrm{mM}$ Tris- $\mathrm{HCl}(\mathrm{pH}$ $=8.3$ ), $75 \mathrm{mM} \mathrm{KCl}, 10 \mathrm{mM}$ DTT, $3 \mathrm{mM} \mathrm{MgCl}_{2}, 2 \mu \mathrm{g}$ nuclease-free $\mathrm{BSA}$, and $200 \mathrm{U}$ of Moloney murine leukemia virus reverse transcriptase (BRL, Gaithersburg, MD). After boiling for $5 \mathrm{~min}$, coamplifica- 
Table I. Detection of INT-2 Expression in KS Lesions

\begin{tabular}{llcc}
\hline \multicolumn{1}{c}{ Samples } & \multicolumn{1}{c}{ Diagnosis } & $\begin{array}{c}\text { Number of } \\
\text { specimens }\end{array}$ & $\begin{array}{c}\text { Number of } \\
\text { positive }\end{array}$ \\
\hline \multirow{2}{*}{ Skin } & AIDS-KS & 27 & 12 \\
& Classic KS & 2 & 2 \\
& KS (HIV-1 negative) & 5 & 3 \\
& Normal & 10 & 1 \\
& $\quad$ (HIV-1 positive) & & \\
& Normal & 2 & 0 \\
Lymph node & (HIV-1 negative) & & \\
Tongue & AIDS-KS & 2 & 2 \\
Lung & AIDS-KS & 1 & 1 \\
& AIDS-KS & 1 & $1 *$ \\
\hline
\end{tabular}

* The expression of int-2 was also detected from the skin of this patient.

tion was performed by adding $20 \mathrm{mM}$ Tris- $\mathrm{HCl}(\mathrm{pH} 8.3$ ), $1.5 \mathrm{mM}$ $\mathrm{MgCl}_{2}, 25 \mathrm{mM} \mathrm{KCl}, 10 \mu$ g gelatin, $200 \mu \mathrm{M}$ of each dNTP, $2.5 \mathrm{U}$ of Taq DNA polymerase and primer pairs for both $\beta$-actin ( $5^{\prime}$-GAG,GAG,CAC,CCC,GTG,CTG,CTG A-3' and 5'-CTA,GAA,GCA,TTT,GCG,GTG,GAC,GAT,GGA,GGG,GCC-3') (12) and int-2 (5'-CTC,TAC,TGC,GCC,ACG,AAG-3' and 5'-GGA,GGC,ATA,CGT,ATT,ATA$\left.3^{\prime}\right),(13)$ followed by 35 cycles of $94^{\circ} \mathrm{C}(1 \mathrm{~min}), 55^{\circ} \mathrm{C}(1 \mathrm{~min})$, and $72^{\circ} \mathrm{C}(1 \mathrm{~min})$. RT-PCR products were analyzed by $2 \%$ agarose gel electrophoresis, Southern blot hybridization with both [ $\left.{ }^{32} \mathrm{P}\right] \mathrm{ATP}$ endlabeled probes for $\beta$-actin ( $5^{\prime}$-GAA,ATC,GTG,CGT,GAC,ATT,AAG,GAG,AAG-3') and int-2 (5'-GTG,GAT,CCG,CTC,CAC,AAA,CTC,GCA,CTC-3'). After washing in $0.5 \times$ sodium chloride sodium phosphate EDTA buffer (SSPE) $\left(75 \mathrm{mM} \mathrm{NaCl}, 5 \mathrm{mM} \mathrm{NaH}_{2} \mathrm{PO}_{4}\right.$, and 0.5 mM EDTA) at $55^{\circ} \mathrm{C}$, autoradiograms were obtained by exposure of Kodak x-ray film at $-70^{\circ} \mathrm{C}$.

$D N A$ sequencing. Bands of the predicted amplified int- 2 cDNA fragment were purified and cloned into TA vector (Invitrogen, San Diego, CA). These fragments were then sequenced using ${ }^{35}$ S-ATP and the Sequenase kit (U.S. Biochemical Corp., Cleveland, OH). The reverse primer was also used to confirm the sequencing data.

Immunochemical staining. Sections ( $4 \mu \mathrm{m}$ thick) from formalinfixed KS biopsy specimens were cut, dehydrated in xylene, rehydrated followed by blocking the endogenous peroxidase with $1 \%$ hydrogen peroxide in methanol. The sections on slides were then sequentially incubated with normal rabbit serum at room temperature for $20 \mathrm{~min}$, and a 1:1,000 diluted polyclonal sheep antibody to int- 2 oncoprotein (Cambridge Research Biochemicals, Cambridge, MA) overnight at $4^{\circ} \mathrm{C}$. An avidin-biotin-peroxidase technique (Vector Laboratories Inc., Burlingame, CA) was used employing rabbit anti-sheep reagents and 3,3-diaminobenzidine (14). The antibody to int-2, which was absorbed with human int-2 peptide, (Cambridge Research Biochemicals) was used as a negative control.

Southern blot hybridization. High molecular weight DNAs were prepared from KS lesions and normal skin by using the method previously described (15). DNAs were digested with PstI, electrophoresed on a $0.7 \%$ agarose gel and transferred to Gene Screen Plus membranes (Dupont, Boston, MA). The membrane was first prehybridized in buffer containing $1 \%$ SDS, $1 \mathrm{M}$ sodium chloride, and $10 \%$ dextran sulfate at $65^{\circ} \mathrm{C}$ for $30 \mathrm{~min}$ and then hybridized in the same buffer with denatured $\left[{ }^{32} \mathrm{P}\right]$ CTP-labeled BK4 probe (a 1.03-kb BamHl-Kpn fragment from human int-2, kindly provided by Dr. C. Dickson, Imperial Cancer Research Fund Laboratories, London) with salmon sperm DNA $(100 \mu \mathrm{g} / \mathrm{ml})$. Probe for fos gene was used as an internal control. After hybridization, the membrane was washed with $15 \mathrm{mM} \mathrm{NaCl} / 1.5$ $\mathrm{mM}$ sodium citrate, $\mathrm{pH} 7.0$, containing $0.5 \%$ sodium dodecyl sulfate at $60^{\circ} \mathrm{C}$ for a total of $60 \mathrm{~min}$ with two changes of the washing solution.

\section{Results}

Int-2 expression in $\mathrm{KS}$ tissues was assessed by reverse transcription of the RNA followed by PCR (RT-PCR). The int-2 primer pair used for the PCR studies was chosen from different exons of int- 2 to prevent amplification of any contaminating genomic DNA sequences. We used coamplification of RNAs of the int- 2 gene and a reporter gene, $\beta$-actin, which enabled us to determine whether the RNA from the different samples studied were amplifiable.

RT-PCR products from KS tumors and normal skin specimens were analyzed by gel electrophoresis and Southern blot. Most of the samples revealed amplification of a $\beta$-actin fragment ( $834 \mathrm{bp}$ ) which demonstrated that the RT-PCR was successful. Amplified fragments of int-2 (252 bp) were found in more than half of the KS tissues examined. After Southern blot hybridization using int- 2 and $\beta$-actin-specific probes and high stringency washes, appropriate bands were clearly detectable, which further confirmed that int-2 gene was expressed in these $\mathrm{KS}$ tumors (Fig. 1). Expression of int-2 was detected in 21 out of 38 of the fresh KS tumor samples (55.2\%). In contrast, we were unable to detect int- 2 mRNA transcripts in the normal appearing skin from the same patients except in one specimen which was obtained from an AIDS patient with disseminated KS lesions. Furthermore, we were unable to detect int-2 mRNA in normal skin from HIV-seronegative individuals. This result is consistent with previous observations that int-2 transcription is not detected in normal adult tissues (16).

To confirm further that the amplified products obtained were generated from int- 2 mRNA, we purified the int- 2 fragment from the gel, subcloned it into the TA vector (Invitrogen) and sequenced it. The sequence data obtained from nine different KS samples demonstrated that the amplified sequences were derived from int- 2 mRNA with proper splicing. Surpris-

A
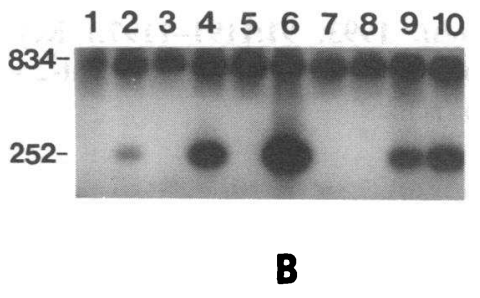

$\begin{array}{llllllllll}1 & 2 & 3 & 4 & 5 & 6 & 7 & 8 & 9 & 10\end{array}$

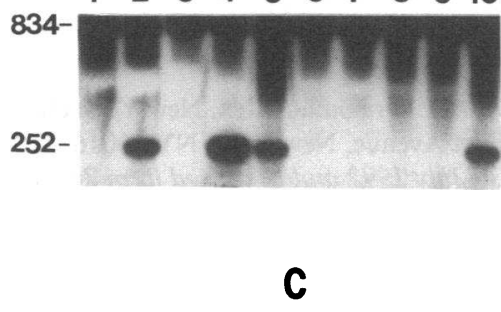

$\begin{array}{lllllllll}1 & 2 & 3 & 4 & 5 & 6 & 7 & 8 & 9\end{array}$

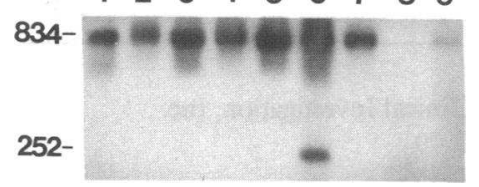

Figure 1. Representative autoradiograms of Southern blots performed on RT-PCR coamplification products hybridized with $\left[{ }^{32} \mathrm{P}\right]$ ATP end-labeled probes for both $\beta$-actin and int-2. A 1-10, B1-5, and $B 10$ are samples from KS lesions; B6, B9, and C1-9 are samples of normal appearing skin obtained from the same patients as B5, $B 10$, and A1-9, respectively. B7 and B8 are samples from HIV-1-negative individuals. Since C8 did not show a $\beta$-actin band, the original sample probably did not contain intact RNA. The sizes of the specific fragments amplified are indicated. 


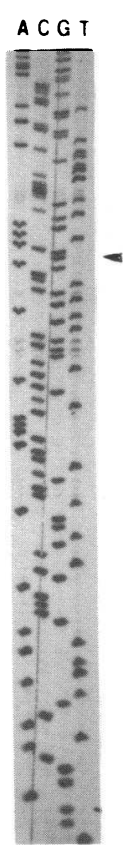

1

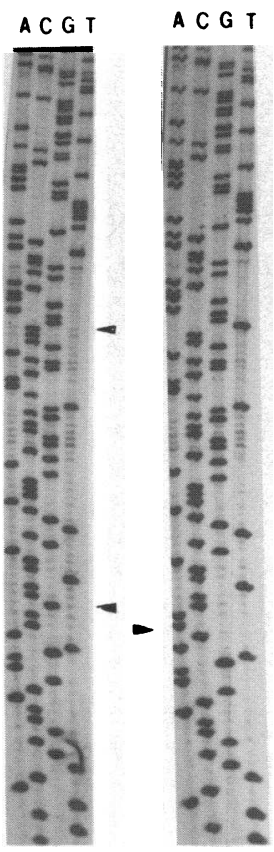

2

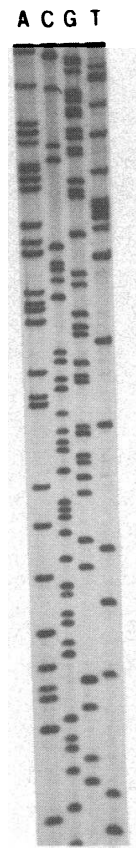

4

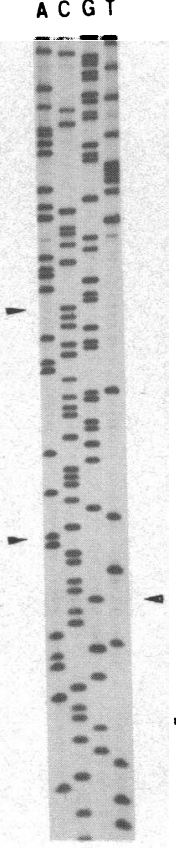

5

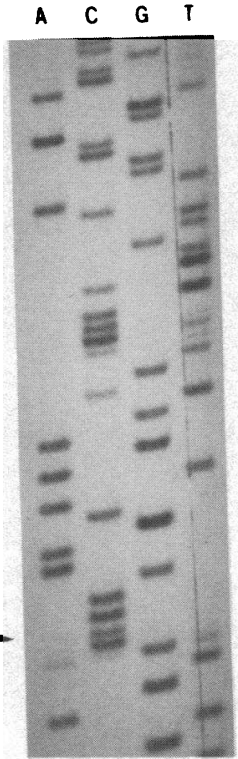

6

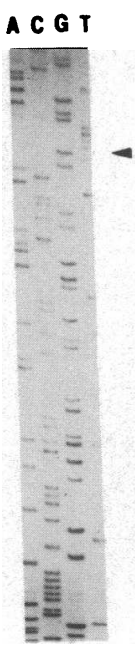

7

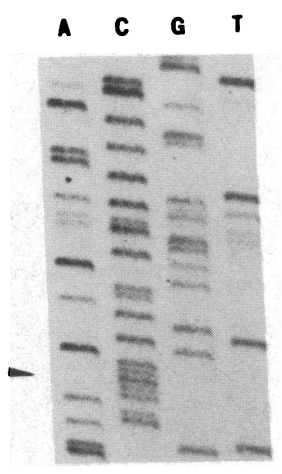

8

Figure 2. Sequence analysis of RT-PCR products of int-2 gene from eight KS lesions. Arrows show the altered base. The number of the sequencing gels are corresponding to that shown in Table II.

ingly, we found nucleic acid sequence alterations in eight out of nine KS tumor samples when compared with the published human int-2 cDNA sequence (13). The observed changes were confirmed by resequencing using a reverse primer. As shown in Fig. 2, the number of differences in an individual sample varied from 1 to 3 , and a total of 12 alterations were identified in 8 of the 9 different $\mathrm{KS}$ specimens examined.

Most of the variations in int-2 cDNA sequences identified were located in exon 1, although four occurred in exons 2 and 3 ; three of which were near the splice sites. While two of the altered cDNA sequences would cause no change in the encoded protein, the others would result in amino acid substitu- tions. Some of these substitutions occur in a conserved domain of members of the FGF family (Fig. 3; Table II).

To determine whether the int- 2 protein is also expressed in KS tissue, we performed immunostaining with antibodies against an int-2 peptide on formalin-fixed tissue sections from $10 \mathrm{KS}$ biopsy samples. Three samples which showed expression of int-2 mRNA were also found to be positive. The int-2 oncoprotein was detected in some of the KS spindle-shaped cells, predominantly those found around the irregular-shaped vascular slits histologically characteristic of KS. Furthermore, int-2 specific staining was present in both the nuclei and cytoplasm with more pronounced expression in the nuclei (Fig. 4).

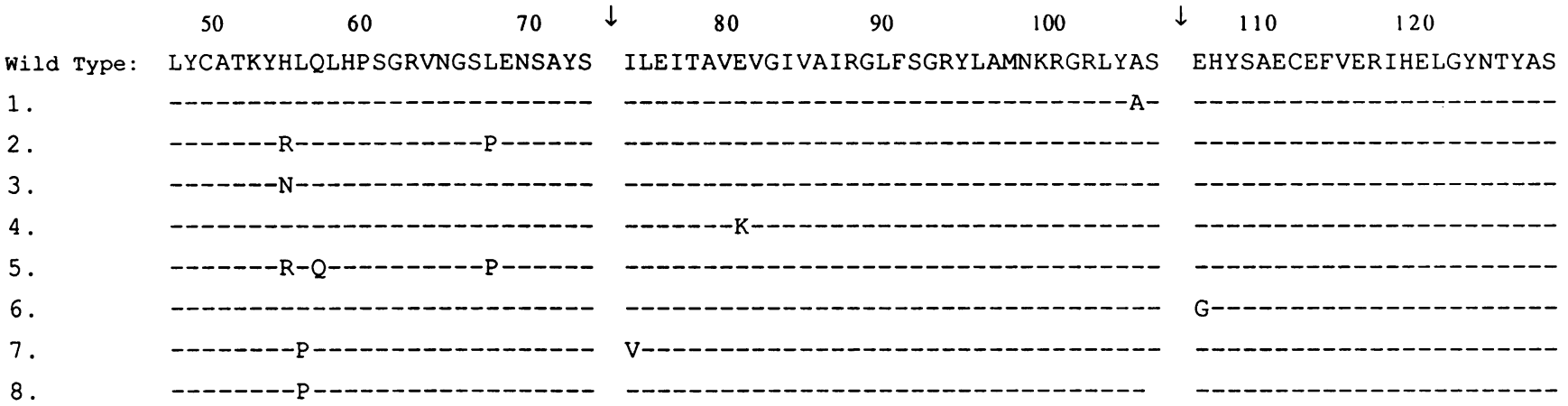

Wild Type: part of published int-2 amino acid sequence(13)

1-8: the alterations found in different $\mathrm{kS}$ lesions shown in $\mathrm{fig} .2$

--- Indicate sequence data identical to wild type

$\downarrow \quad$ Represents the exon boundaries

the amino acid sequence number of int-2 is shown above

Figure 3. Predicted substitutes of human int-2 amino acid sequence due to nucleic acid alterations. 

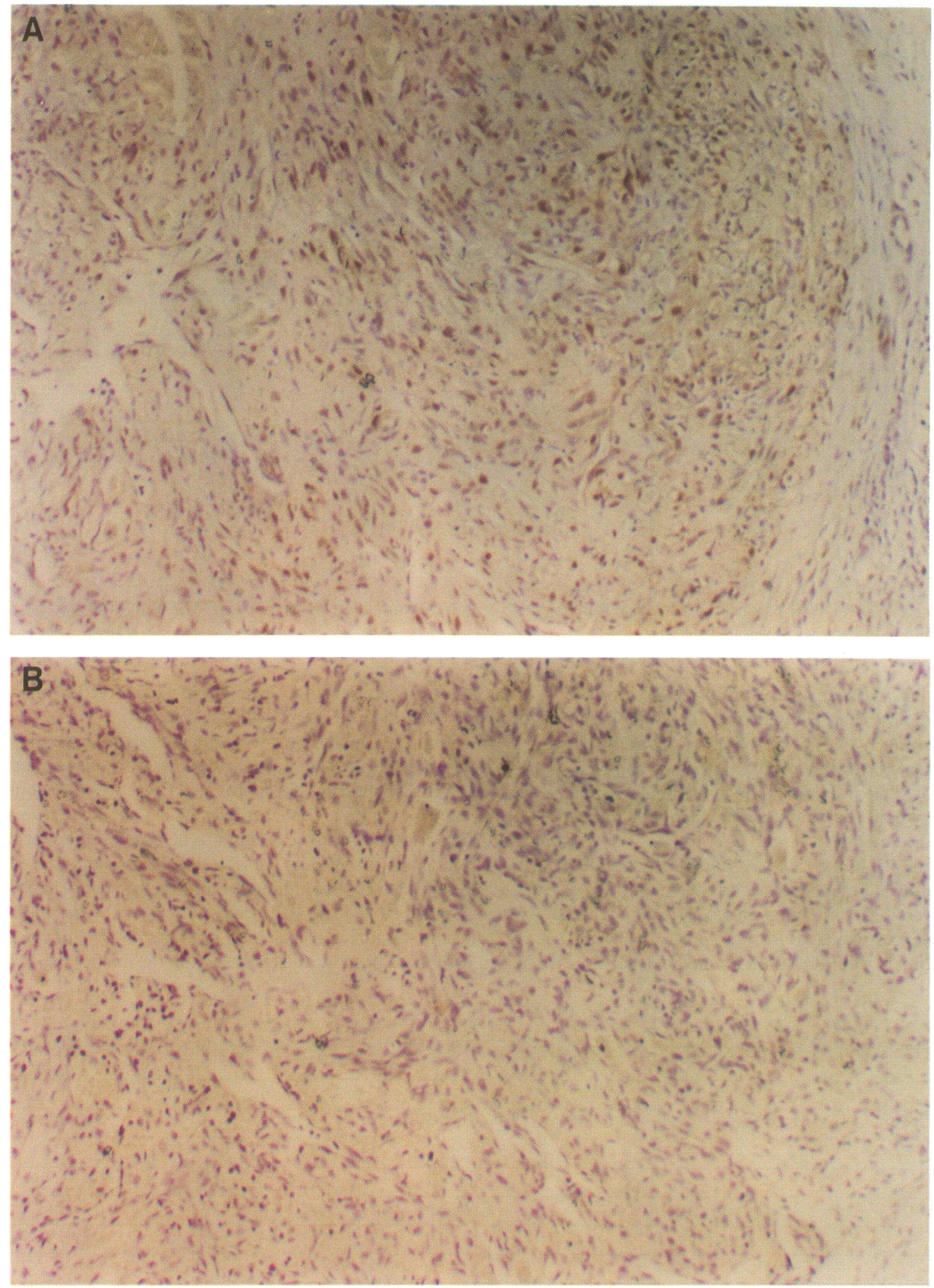

Figure 4. Immunostaining for int-2 protein in tissue specimens of KS lesions. $(A)$ KS lesion with anti-int-2-positive brown stained spindleshaped cells $(\times 100) .(B)$ Control immunostaining for int-2 protein in the presence of excess synthetic peptide $(\times 100)$. $(C)$ KS lesion showing positive perivascular spindle-shaped cell $(\times 200)$. (D) High power view of anti-int-2 positive spindle shaped cells with nuclear and/or cytoplasmic staining $(\times 400)$. 

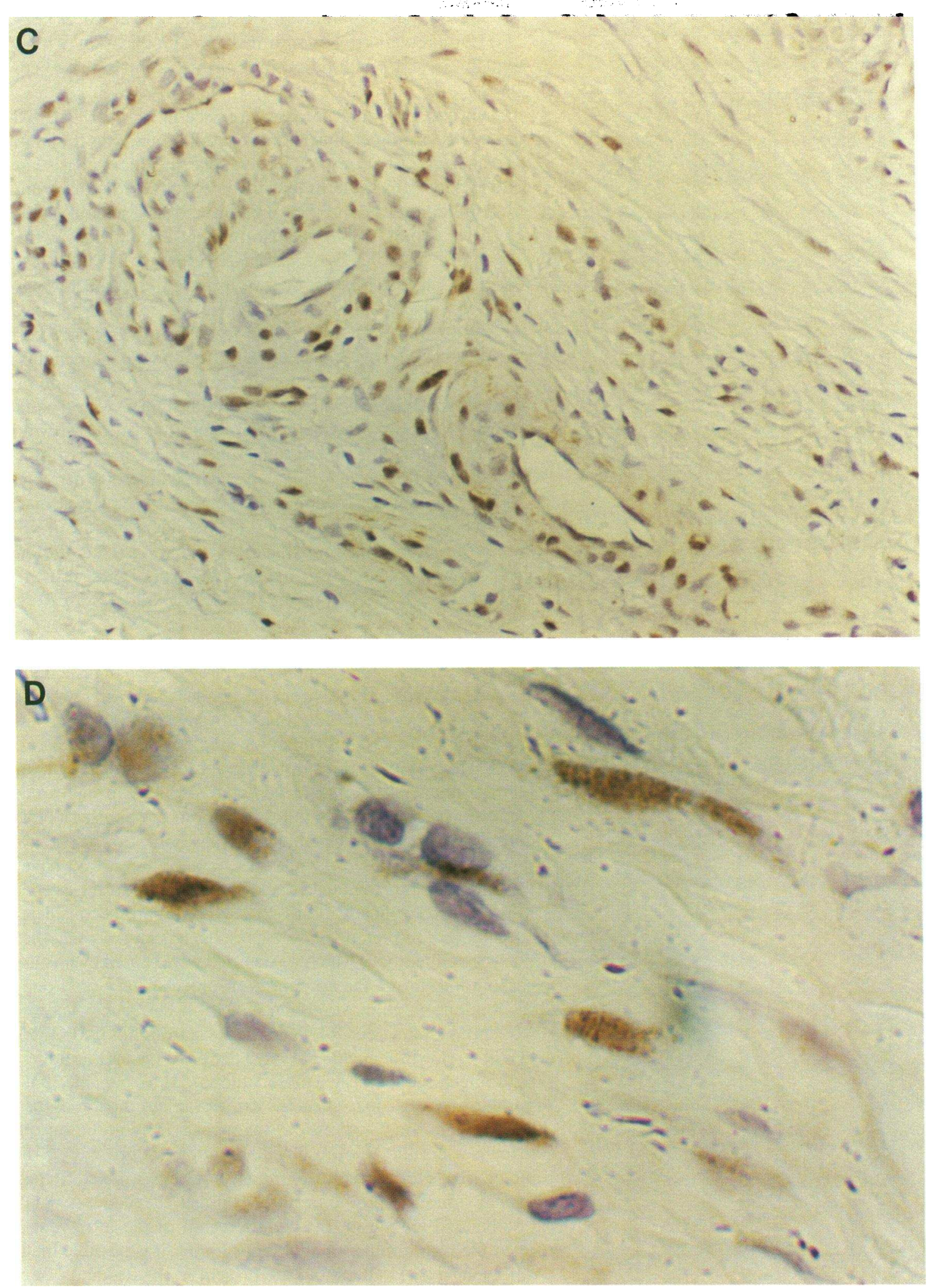

Figure 4 (Continued)

No positive staining for int- 2 was observed in sections of normal skin.

The mechanism of activation of the int- 2 gene is not clear. To test whether int- 2 activation associated with gene amplifica- tion or rearrangement, genomic DNAs were extracted from KS and normal skin tissues, digested with restriction endonuclease PstI, Southern blotted, and hybridized with an int-2 specific probe. As shown in Fig. 5, each sample yielded a pattern of 
Table II. Alterations of INT-2 Amino Acids in KS Lesions

\begin{tabular}{ccc}
\hline $\begin{array}{c}\text { KS } \\
\text { lesion }\end{array}$ & $\begin{array}{c}\text { Altered } \\
\text { codon no. }\end{array}$ & $\begin{array}{c}\text { Amino acid } \\
\text { substitution }\end{array}$ \\
\hline 1 & 107 & Ala $\rightarrow$ Ala \\
2 & 55 & His $\rightarrow$ Arg \\
& 68 & Leu $\rightarrow$ Pro \\
3 & 55 & His $\rightarrow$ Asn \\
4 & 82 & Glu $\rightarrow$ Lys \\
5 & 55 & His $\rightarrow$ Arg \\
& 57 & Gln $\rightarrow$ Gln \\
& 68 & Leu $\rightarrow$ Pro \\
6 & 109 & Glu $\rightarrow$ Gly \\
7 & 56 & Le $\rightarrow$ Pro \\
& 75 & Ile $\rightarrow$ Val \\
8 & 56 & Leu $\rightarrow$ Pro \\
9 & None &
\end{tabular}

bands of identical sizes when hybridized to the int- 2 probe. The int-2-specific bands had equivalent intensities when normalized to a fos probe used as an internal control.

\section{Discussion}

Int-2 seems to be expressed primarily during embryonic development and has not been detected in any normal adult tissues (16-18). However, inappropriate expression of int- 2 in the adult may have a role in the pathogenesis of certain tumors. The int- 2 gene was originally identified as a site of frequent insertion of the murine mammary tumor virus which activated the transcription of the cellular gene leading to tumor formation in mice (19). Expression of int- 2 in NIH3T3 cells has been shown to transform these cells $(20)$. The oncogenic potential of int -2 has also been confirmed in transgenic mice (21). The amplification of int-2 gene has been described in 9-23\% of human breast cancer specimens examined and the amplification of int-2 together with K-FGF has also been reported in a
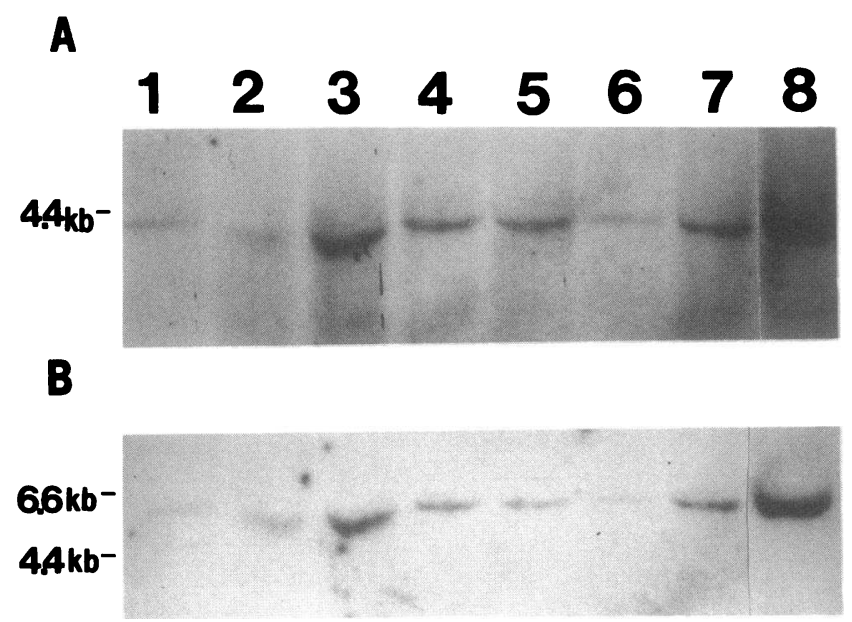

Figure 5. Southern blot hybridizations on KS lesion and normal skin DNAs. (Lanes 1-6) DNAs from KS lesions. (Lanes 7 and 8) DNAs from normal skin. $(A)$ Southern blot probed with int-2 fragment. $(B)$ Southern blot probed with fos fragment. DNA fragment sizes are shown on the left. few other human carcinomas involving the head and neck (2227 ). It still remains to be confirmed that amplification of int-2 actually coincides with transcriptional activation in these neoplasms.

Our data show that int- 2 is expressed in $>50 \%$ of the KS specimens examined. Furthermore, int- 2 protein was found to be expressed in both nuclei and cytoplasm. This is consistent with previous observations that an int- 2 product resulting from AUG-initiation is found predominantly in the secretory pathway whereas the CUG-initiated form of int- 2 was located in the nucleus in COS- 1 cells transfected with int- 2 cDNA (28). These findings suggest that the two forms of int-2 oncoprotein are also produced in KS lesions. The FGF receptors flg and bek are expressed in $\mathrm{KS}$ lesions. These receptors are able to recognize several members of the FGF family, although their affinity for the int- 2 protein is still not yet clear. The coexpression of secretory int- 2 protein with these receptors may provide a basis for autocrine and/or paracrine stimulation of $\mathrm{KS}$ cell growth in these tumors. In addition to its transforming activity, int-2 protein is related to factors having angiogenic properties. We observed that int- 2 is predominantly expressed in perivascular cells of KS. The expression of int-2 thus could participate in KS tumor formation by stimulating local angiogenesis and tumor cell proliferation. Moreover the nuclear form of int-2 protein may play a role directly in the intracellular processes in $\mathrm{KS}$ oncogenesis.

The mechanism for the activation of the int-2 gene in KS tumor is not clear. It is possible that the activation of int- 2 may be caused by specific viral agent(s), similar to the activation of int- 2 in mice by murine mammary tumor virus. Epidemiological and laboratory data strongly suggest that KS may be associated with a sexually transmitted agent (29). Amplification or rearrangement of the int- 2 gene could also lead to increased expression of int- 2 mRNA in KS. However, our Southern blot data demonstrated that neither amplification nor gross rearrangement of the int-2 gene was present in $\mathrm{KS}$ lesions. We have identified a number of nucleic acid alterations in the int- 2 gene in KS tissue. The fidelity of RT-PCR is an important consideration in the interpretation of these results. It is unlikely that the nucleotide alterations which we detected were caused by misincorporation during the amplification process, since only one silent point mutation was found in an FGFR-2 gene when we sequenced 18 different RT-PCR products from bFGF, FGF5, FGFR-1, FGFR-2, and P53 (exon 3 to exon 5) genes in parallel experiments (unpublished observations). It is possible that mutations of int- 2 may effect the expression or function of the int- 2 protein. Int- 2 expression was increased by mutation of sequences around the presumed initiation codon in COS-1 monkey cells transfected with mouse int- 2 DNA linked to the Simian virus early promotor (30). Although the sequence data we obtained are within the coding region of the int- 2 gene, given the high number of alterations found, it is possible that other nucleic acid alterations are present in the regulatory sequences of the int- 2 gene. The possible role of alterations of the int-2 gene in the pathogenesis of KS needs to be further evaluated.

\section{Acknowledgments}

Special thanks to Peter A. Pope and Karen Crawford for preparing this manuscript. 
This work was supported by The Howard Gilman Foundation, by grant CA 42229 from the National Institutes of Health, and by a grant to Dr. Poiesz (2401A127658-06 from the AIDS Cooperative Treatment Group of the National Institute of Allergy and Infectious Diseases).

\section{References}

1. Friedman-Kien, A. E. 1981. Disseminated Kaposi's sarcoma syndrome in young homosexual men. Am. Acad. Dermatol. 5:468-471.

2. Ensoli, B., S. Nakamura, S. Z. Salahuddin, P. D. Biberfeld, L. Larsson, B. Beaver, F. Wong-Staal, and R. C. Gallo. 1989. AIDS-Kaposi's sarcoma-derived cells express cytokines with autocrine and paracrine growth factors. Science (Wash. DC). 243:223-226.

3. Miles, S. A., A. R. Rezai, A. F. Salazar-Gonzalez, M. V. Meuyden, R. H Stevens, D. M. Logan, R. T. Mitsuyasu, T. Taga, T. Hirano, T. Kishimoto, and O. Martinez-Maza. 1990. AIDS Kaposi's sarcoma-derived cells produce and respond to interleukin 6. Proc. Natl. Acad. Sci. USA. 87:4068-4072.

4. Werner, S., P. H. Hofschneider, and W. K. Roth. 1989. Cells derived from sporadic and AIDS-related Kaposi's sarcoma reveal identical cytochemical and molecular properties in vitro. Int. J. Cancer. 43:1137-1144.

5. Nait, B. C., A. L. DeVico, S. Nakamura, T. D. Copeland, T. Chen, A. Patel, T. Oneil, S. Oroszlan, R. C. Gallo, and M. G. Sarngaddharan. 1992. Identification of major growth factor for AIDS-Kaposi's sarcoma cells as oncostation M. Science (Wash. DC). 255:1430-1432.

6. Miles, S. A., O. Martinez-Maza, A. Rezai, L. Magpantay, T. Kishimoto, S Nakamura, S. F. Radka, and P. S. Linsley. 1992. Oncostatin M as a poten mutagen for AIDS-Kaposi's sarcoma-derived cells. Science (Wash. DC) 255:1432-1434.

7. Basilico, C., and D. Moscatelli. 1992. The FGF family of growth factors and oncogenes. Adv. Cancer Res. 59:115-165.

8. Xerri, L., J. Hassoun, J. Plance, V. Guigou, J. J. Grobb, P. Patricza, D. Birnbaum, and O. deLapeyriere. 1991. Fibroblast growth factor gene expression in AIDS-Kaposi's sarcoma detected by in situ hybridization. Am. J. Pathol. 138:9-15.

9. Schulze-Osthoff, K., S. Goerdt, and C. Sorg. 1990. Expression of basic fibroblast growth factor (bFGF) in Kaposi's sarcoma: an immunohistologic study. J. Invest. Dermatol. 95:238-240.

10. Chomczynski, P., and N. Sacchi. 1987. Single-step method of RNA isolation by acid guanidinium thiocyanate-phenol-chloroform extraction. Anal. Biochem. 162:156-159.

11. Byrne, B. C., J. J. Li, J. Sminsky, and B. J. Poiesz. 1988. Detection of HIV-1 RNA sequences by in vitro DNA amplification. Nucleic Acids Res. $16: 4165$.

12. Nakajima-lijima, S., H. Hamada, P. Reddy, and T. Kakunaga. 1985. Molecular structure of the human cytoplasmic $\beta$-actin gene: interspecies homology of sequences in the introns. Proc. Natl. Acad. Sci. USA. 82:6133-6137.

13. Brookes, S., R. Smith, G. Casy, C. Dickson, and G. Peters. 1989. Sequence organization of the human int- 2 gene and its expression in teratocarcinoma cells. Oncogene. 4:429-436.

14. Li, J. J., Y. Q. Huang, B. J. Poiesz, and A. E. Friedman-Kien. 1992.
Detection of human immunodeficiency virus type 1 (HIV-1) in urine cell pellets from HIV-1-seropositive individuals. J. Clin. Microbiol. 30:1051-1055.

15. Sambrook, J., E. F. Fritsch, and T. Maniatis. 1989. Molecular Cloning: A Laboratory Manual. Cold Spring Harbor Laboratory, Cold Spring Harbor, New York. 2nd edition.

16. Jakobovits, A., G. M. Shackleford, H. E. Varmus, and G. R. Martin. 1986 Two proto-oncogenes implicated in mammary carcinogenesis, int-1 and int-2, are independently regulated during mouse development. Proc. Natl. Acad. Sci. USA. 83:7806-7810.

17. Wilkinson, D. G., G. Peters, C. Dickson, and A. P. McMahon. 1988 Expression of the FGF-related proto-oncogene int-2 during gastrulation and neurulation in the mouse. EMBO (Eur. Mol. Biol. Organ.) J. 7:691-695.

18. Wilkinson, D. G., S. Bhatt, and A. P. McMahon. 1989. Expression pattern of the FGF-related proto-oncogene int- 2 suggests multiple roles in fetal development. Development (Camb.). 105:131-136.

19. Dickson, C., R. Smith, S. Brookes, and G. Peters. 1984. Tumorigenesis by mouse mammary tumor virus: proviral activation of a cellular gene in the common integration region int-2. Cell. 37:529-536.

20. Goldfarb, M., R. Deed, D. MacAllan, W. Walther, C. Dickson, and G. Peters. 1991. Cell transformation by int-2-a member of the fibroblast growth factor family. Oncogene. 6:65-71.

21. Muller, W. J., F. S. Lee, C. Dickson, G. Peters, P. Pattengal, and P. Leder. 1990. The int-2 gene product acts as an epithelial growth factor in transgenic mice. EMBO (Eur. Mol. Biol. Organ.) J. 9:901-913.

22. Liscia, D. S., G. R. Merlo, C. Garrett, D. French, R. Marianai-Costatini, and R. Callahan. 1989. Expression of int- 2 mRNA in human tumors amplified at the int-2 locus. Oncogene. 4:1219.

23. Theillet, C., X. Leroy, O. deLapeyriere, J. Grosgeorges, J. Adriane, S. D. Raynaud, J. Simony-Lafontaine, M. Goldfarb, C. Escot, D. Birnbaum, and P. Gaudray. 1989. Amplification of FGF-related genes in human tumors: possible involvement of HST in breast carcinomas. Oncogene. 4:915-922.

24. Fantl, V., S. Brookes, and R. Smith. 1989. Characterization of the protooncogene int-2 and its potential for the diagnosis of human breast cancers. Cancer Cells (Cold Spring Harbor). 7:283.

25. Borg, A., H. Sigurdeson, G. M. Clark, M. Ferno, S. A. W. Fuqua, H. Olsson, D. Killander, and W. L. McGurie. 1991. Association of int-2/HST-1 coamplification in primary breast cancer with hormone-dependent phenotype and poor prognosis. Br. J. Cancer. 63:136-142.

26. Tsutsumi, M., H. Sakamoto, T. Yoshida, K. Kakizoe, K. Koiso, T. Sugimura, and M. Terada. 1988. Coamplification of the HST-1 and int-2 genes in human cancers. Jpn. J. Cancer Res. 79:428-432.

27. Tsuda, T., H. Nakatani, T. Matsumura, K. Yoshida, E. Tahara, T. Nishihira, H. Sakamoto, T. Yoshida, M. Terada, and T. Sugimura. 1988. Amplification of the HST-1 gene in human esophageal carcinomas. Jpn. J. Cancer Res. 79:584-588.

28. Acland, P., M. Dixon, G. Peters, and C. Dickson. 1990. Subcellular fate of the int-2 oncoprotein is determined by choice of initiation codon. Nature (Lond.). 343:662-665

29. Beral, V., T. A. Peterman, R. L. Berkelman, and H. W. Jaffe. 1990. Lancet. 335:123-128.

30. Dixon, M., R. Deed, P. Acland, R. Moore, A. Whyte, G. Peters, and C. Dickson. 1989. Detection and characterization of the fibroblast growth factor-related oncoprotein int-2. Mol. Cell. Biol. 9:4896-4902. 